\title{
7 Travel Behaviour of Car Users During the UK Fuel Crisis and Insights into Car Dependence KIRON CHATTERJEE AND GLENN LYONS
}

\section{Introduction}

For one week in September 2000 the pumps ran dry in filling stations across the UK. Motorists were unsure when they would be able to refill their vehicles and journeys by car that would previously have been taken for granted were scrutinised and assessed in terms of their necessity and efficiency. A national opinion poll found that 29 per cent of the GB population with a car available to them said they ran so low on petrol they had to stop using their car (ICMa, 2000).

Cars are a central part of most people's lifestyles in the UK and it is not surprising that the public react with caution to transport policies that could restrict use of their cars. Opportunities to explore the response in practice of car users when use of their cars is compromised are rare. The fuel crisis presented such an opportunity on an unprecedented scale.

This chapter describes the results of a mailback questionnaire survey of car users undertaken immediately after the fuel crisis. It starts by briefly summarising what is known about car user behaviour and what further understanding might be gained from a survey at the time of the fuel crisis. There are then some details of the design and distribution of the survey. Chapter 11 (Lyons and Beecroft, 2002) has a detailed account of how the survey was conducted. The chapter then explains how the survey information was processed into a form amenable to analysis and describes the sample of responses received. The main part of the chapter describes the results of the survey. The interpretation and implications of the results are discussed before the chapter concludes with recommendations on policies to reduce car use.

\section{Car Dependence}


Increasing car use leads to congestion, delays, pollution, accidents, higher costs as well as reduced opportunities for those without access to a car. The need to develop more sustainable patterns of mobility, whilst not compromising economic prosperity and the choices available to individuals, continues to be a goal for policy-makers both in the UK and many other countries. The UK government's ten year plan for Transport (DETR, 2000) aims to increase the share of travel undertaken by alternatives to the car, whilst recognising that there will continue to be a growth in travel demand and car ownership.

A report on car dependence noted that:

At the time of first purchase, the car may be seen as a luxury. However, once bought, it encourages changes in behaviour and circumstances which in effect turn it into a necessity. Car dependence grows, rather than simply existing. (Goodwin, 1995)

Nevertheless, it is considered that about 20 per cent of car trips are marginal and could easily be undertaken by other means. The report suggests that:

In order to target policies effectively, further research will be needed to identify the characteristics of the trips in ... more detail.

Examining the behaviour of car users during the fuel crisis should be able to shed light on the car trips that are most amenable to change and what might be done in policy terms to bring about sustained change to these trips. It should also deepen our understanding of the constraints and difficulties of bringing about change to the other 80 per cent of trips made by car.

It is increasingly recognised by those seeking to understand and predict travel behaviour that travel needs to be viewed in the context of the activities that people pursue. Bhat and Koppelman (2000) have found that studies of travel behaviour taking an activity-centred approach have given an insight into people's routines, household interactions and constraints, and the effects of these on travel. Such studies have usually focussed on specific groups of the population or specific circumstances, and have rarely been able to examine what happens when a major intervention occurs. The fuel crisis provided the opportunity to better understand the ways car users prioritise their activities/trips and reorganise them when they are unable to follow their intended routine. 


\section{Car User Survey}

Chapter 11 explains the choice of survey method and provides a detailed account of how the survey was conducted. In short, there was a need to capture details of changes to behaviour that occurred during the fuel crisis very quickly before memories faded. Given the absence of any advance warning of the fuel crisis (and hence the lack of any survey planning) a method was required that would yield a large number of responses in a short space of time without the use of a trained survey team. A selfcompletion questionnaire was used for the survey as it met these criteria as well as enabling detailed accounts of behaviour to be recorded by respondents.

The fuel crisis affected all forms of transport (for example, public transport experienced overcrowding and service cancellations due to drivers not being able to get to work). The aim of the survey, however, was to find out how car users changed their travel behaviour as a result of the fuel shortage. Car use involves those who drive and those who are passengers and includes people who have access to a car at home and those who use pool cars, hire cars or get lifts. The questionnaire was designed to obtain details about all these types of car use. (Private van use was considered in the same way as car use.)

The questionnaire sought to find out about car users' travel behaviour by asking respondents to record their usual travel behaviour and how this had been affected by the fuel crisis. An alternative approach would have been to design the questionnaire as a travel diary. Travel diaries involve subjects recording a chronological account of individual trips and activities. To have been appropriate in this situation, a 'before' survey would need to have been conducted to capture usual travel behaviour. Furthermore, travel diaries would need to have been distributed before the start of the fuel crisis so they could be completed during it. Our approach of asking about change to usual travel behaviour was believed to be appropriate given that the questionnaires were distributed a few days after the fuel crisis. We expected that people would still be able to recollect changes made.

As well as asking for details of changes made to travel, respondents were also asked to give details of any effects the changes had on other activities and household routines. The aim was to get an understanding of the constraints on making changes and the implications of making changes on other aspects of people's lives. 
The questionnaire is included at the end of Chapter 11. The main part of the questionnaire centred on four travel purposes: the journey to/from work (commuting); journeys made whilst at work (business); escorting children to/from school or pre-school (school); and grocery shopping (groceries). Table 7.1, which is based on national transport statistics (DETR, 2001), shows that travel for these purposes comprises a substantial proportion of all travel undertaken. Commuting, business, escort education and shopping account for 46 per cent of all car trips and 45 per cent of car travel distance.

\section{Table 7.1 Average annual travel by purpose in GB}

\begin{tabular}{lcccc}
\hline Purpose & $\begin{array}{c}\text { Travel by all modes } \\
\text { \% of } \\
\text { trips }^{\mathrm{a}}\end{array}$ & $\begin{array}{c}\text { Travel by car } \\
\text { \% of } \\
\text { distance }^{\mathrm{b}}\end{array}$ & $\begin{array}{c}\text { \% of } \\
\text { trips }^{\mathrm{c}}\end{array}$ & $\begin{array}{c}\text { \% of } \\
\text { distance }^{\mathrm{d}}\end{array}$ \\
\hline Commuting & 16 & 20 & 18 & 19 \\
$\begin{array}{l}\text { Business } \\
\text { Education }\end{array}$ & 4 & 10 & 4 & 11 \\
$\begin{array}{l}\text { Escort education } \\
\text { Shopping }\end{array}$ & 5 & 3 & 3 & 2 \\
$\begin{array}{l}\text { Leisure } \\
\text { Other personal }\end{array}$ & 21 & 1 & 4 & 2 \\
and escort & 31 & 40 & 20 & 13 \\
\hline
\end{tabular}

a Average annual total trips by all modes $=1,046$

b Average annual total distance by all modes $=6,806$ miles

c Average annual total trips by car $=646$

d Average annual total distance by car $=5,546$ miles

The questionnaire had eight sections.

- Section 1: asked for details of the respondent and their household, including age, gender, occupation, available cars and whether cars refuelled at start of fuel crisis week.

- Sections 2 to 5: applied to the four travel purposes mentioned above and asked for details of usual routine, whether any change made to 
usual routine (including details of change made and reasons why not if no change made), whether change had been made before in last six months and whether consideration would be given to making change again in future.

- Section 6: asked if other changes had been made to travel and usual routine, including any combining of trips and activities, any cancellations and postponements of trips and activities, any extra use of the phone or Internet and any seeking of public transport information.

- Section 7: asked for views on eleven specific statements related to the fuel crisis (e.g. 'did the fuel crisis make you realise you use your car more than necessary').

- Section 8: provided space for respondents to note any other things that they wished to say about the fuel crisis and future levels of car use, fuel tax or related issues.

A key feature of the questionnaire is that open response questions were used where respondents were invited to describe in their own words what changes they had made and why. The alternative was to have used closed response questions where respondents were asked to note which of a set of option answers applied to them. Without time to pilot the questionnaire it was not possible to identify the range of different changes to car use that were made during the fuel crisis and to establish appropriate answer options. Closed response questions would have proved vastly more manageable and straightforward in analysis terms but would have compromised the aim of capturing the full breadth of circumstance and types of change that were made.

Mailback questionnaires were distributed to the public door-to-door, in town and city centres and via petrol filling stations, primary schools and employers. They were distributed in five areas of England (Hampshire/Wiltshire, West Yorkshire, London Borough of Hillingdon, Leicester and Hertford). A total of over 10,000 mailback questionnaires were distributed. In addition to the distribution of mailback questionnaires, a duplicate version of the questionnaire was created for the web. This allowed individuals with access to the Internet from any physical location in the UK to participate in the survey. This chapter only presents results of the mailback questionnaire.

Chapter 11 has a more detailed account of the survey distribution and an analysis of the response rates achieved for different distribution methods. 


\section{Fuel Crisis Survey Sample}

\section{Overall Sample}

A total of 1,659 usable responses was received. A cut off date for usable responses of 19 October (34 days after the end of the fuel crisis on 15 September) was applied. This was an attempt to minimise the inclusion of responses that would contain distorted or vague recollections of events, behaviour and attitudes during the crisis. In fact, 88 per cent of the 1,659 responses were received within 14 days of 15 September.

\section{Data Processing}

A major consequence of having many open response questions was the substantial time required to firstly transcribe the questionnaire responses and secondly process the responses and categorise them to enable quantitative analysis to be carried out. Table 7.2 is a listing of variables created from open response questions.

In categorising the response information in sections 2-6 a compromise had to be made between capturing the enormous variety of behavioural change that occurred and obtaining meaningful insights into the most common changes. To categorise the types of changes made to car use a master-list of 75 different codes was used. The master-list is included at the end of the chapter. The same master-list applied to each of the four travel purposes. The example below for the journey to/from work for respondent \#133 illustrates the task that was involved:

Instead of taking my children to school they cycled there and back. Normally I would take them in the morning and they would bus home in the afternoon. This made it easier for me but my daughter who has a slight physical disability found cycling hard and aggravated her medical problems. (\#133)

This response was coded as type ' 64 ' - went directly to work instead of trip chaining. The detailed codes were also grouped into 13 higher level codes (which applied to the four travel purposes and to other travel - these are also shown on the master-list). In terms of the higher level code, \#133 was coded as a type ' 3 ' trip chaining change.

\section{Sample Representativeness}


The characteristics of the sample were examined carefully to see how representative it was of the general car user population. It was not expected that the sample would be fully representative for a number of reasons. Random sampling of the car user population was not undertaken. Although different areas of the country and different places within each area were targeted the distribution will not reflect the national distribution. Of those receiving a questionnaire, certain types of individual will have been more likely to return them. There is also the likelihood that those with strong opinions on the subject of the survey will have been more likely to respond.

Table 7.3 presents characteristics of the fuel crisis sample alongside comparative figures for the general population. The figures for the general population are drawn from a variety of different sources and in some cases apply to all of the population, in other cases to car drivers and in one case to all of the population in employment.

The fuel crisis sample had a higher proportion of females and people aged between 35 and 54 than the general population of car drivers (differences are statistically significant at the 99.9 per cent level). It had more people with occupation types 1-4 than the general population in employment and fewer people with occupation types 5-9 (difference in occupation type distributions is statistically significant at the 99.9 per cent level). 
130 Transport Lessons from the Fuel Tax Protests of 2000

Table 7.2 Variables created from open response questions

\begin{tabular}{|c|c|c|}
\hline Variable & Definition & Categories \\
\hline \multicolumn{3}{|l|}{ Section 1} \\
\hline $\begin{array}{l}\text { Occupation } \\
\text { major group }\end{array}$ & $\begin{array}{l}\text { Classification of occupation } \\
\text { according to standard } \\
\text { occupational classification } 2000 \\
\text { major groups. See ONS (2000). }\end{array}$ & $\begin{array}{l}0=\text { unknown, } \\
1=\text { manager, } . . \\
13=\text { retired }\end{array}$ \\
\hline $\begin{array}{l}\text { Respondent } \\
\text { status }\end{array}$ & $\begin{array}{l}\text { Respondent's status in } \\
\text { household (all house members } \\
\text { considered) }\end{array}$ & $\begin{array}{l}0=\text { unknown, } \\
1=\text { on own,... } \\
9=\text { with other adult co- } \\
\text { residents }\end{array}$ \\
\hline $\begin{array}{l}\text { Household } \\
\text { type }\end{array}$ & $\begin{array}{l}\text { Life-cycle based categories as } \\
\text { used by Jones et al. (1983) }\end{array}$ & $\begin{array}{l}0=\text { unknown, } \\
1=\text { young adult(s) w/out } \\
\text { children,... } \\
8=\text { retired persons }\end{array}$ \\
\hline \multicolumn{3}{|l|}{ Sections 2-5 } \\
\hline Change made & $\begin{array}{l}\text { Changed travel on any day } \\
\text { because of fuel crisis? }\end{array}$ & $\begin{array}{l}0=\text { n/a or unknown, } \\
1=\text { yes, } \\
2=\text { no }\end{array}$ \\
\hline $\begin{array}{l}\text { Reason not } \\
\text { changed }\end{array}$ & $\begin{array}{l}\text { Reason given for not making } \\
\text { any change to travel for this } \\
\text { purpose }\end{array}$ & $\begin{array}{l}0=\text { n/a or unknown, } \\
1=\text { on holiday,... } \\
21=\text { conserved fuel } \\
\text { elsewhere so that car could } \\
\text { be used }\end{array}$ \\
\hline $\begin{array}{l}\text { Type of } \\
\text { change made* }\end{array}$ & $\begin{array}{l}\text { Type of change made on } \\
\text { occasion when usual routine not } \\
\text { followed }\end{array}$ & $\begin{array}{l}0=\text { n/a or unknown, } \\
1=\text { bus,... } \\
84=\text { travel as normal but } \\
\text { destination activity not } \\
\text { possible due to fuel crisis }\end{array}$ \\
\hline $\begin{array}{l}\text { Frequency } \\
\text { change made* }\end{array}$ & $\begin{array}{l}\text { Number of days when change } \\
\text { made }\end{array}$ & $\begin{array}{l}0=\text { n/a or unknown, } \\
1=\text { on one day, } \\
2=\text { on at least one day }\end{array}$ \\
\hline $\begin{array}{l}\text { Reason for } \\
\text { making/not } \\
\text { making } \\
\text { change again* }\end{array}$ & $\begin{array}{l}\text { Main reason for making or not } \\
\text { making change again in future }\end{array}$ & $\begin{array}{l}0=\text { not } \\
\text { applicable/unknown, } \\
1=\text { cost,... } \\
\text { 44=better balanced } \\
\text { lifestyle }\end{array}$ \\
\hline
\end{tabular}

Table 7.2 Variables created from open response questions 
Travel Behaviour of Car Users During the UK Fuel Crisis 131

\begin{tabular}{|c|c|c|}
\hline Variable & Definition & Categories \\
\hline \multicolumn{3}{|l|}{ Section 6} \\
\hline $\begin{array}{l}\text { Other travel } \\
\text { purpose* }\end{array}$ & $\begin{array}{l}\text { Purpose of other type of travel } \\
\text { made on a regular basis }\end{array}$ & $\begin{array}{l}0=\text { not } \\
\text { applicable/unknown, } \\
1=\text { =visit family/friends,... } \\
25=\text { go to concert/theatre }\end{array}$ \\
\hline $\begin{array}{l}\text { Other travel } \\
\text { impact* }\end{array}$ & $\begin{array}{l}\text { Impact of fuel crisis on other } \\
\text { type of travel }\end{array}$ & $\begin{array}{l}0=\text { n/a or unknown, } \\
1=\text { cancelled,... } \\
24=\text { linked to other activity }\end{array}$ \\
\hline \multirow[t]{2}{*}{$\begin{array}{l}\text { Reason used } \\
\text { phone more }\end{array}$} & $\begin{array}{l}\text { Reason made greater use of } \\
\text { phone/Internet during fuel crisis }\end{array}$ & $\begin{array}{l}0=\text { =n/a or unknown, } \\
1=\text { find out where fuel } \\
\text { available,... }\end{array}$ \\
\hline & & $\begin{array}{l}23=\text { =rearranging business } \\
\text { matters }\end{array}$ \\
\hline
\end{tabular}

* Allowance made for details of more than one change to be considered for each respondent for each travel purpose.

Table 7.3 Comparison of fuel crisis sample with general population 
132 Transport Lessons from the Fuel Tax Protests of 2000

\begin{tabular}{|c|c|c|}
\hline Characteristic & $\begin{array}{c}\text { Fuel crisis } \\
\text { sample } \\
(\%)\end{array}$ & $\begin{array}{c}\text { Genera } \\
\text { pop. } \\
\text { (\%) }\end{array}$ \\
\hline Gender & & $\operatorname{Lex}^{\mathrm{a}}$ \\
\hline Male & 50 & 60 \\
\hline Female & 50 & 40 \\
\hline Age group & & $\operatorname{Lex}^{\mathrm{a}}$ \\
\hline $17-34$ & 23 & 30 \\
\hline $35-54$ & 53 & 43 \\
\hline$>54$ & 24 & 28 \\
\hline $\begin{array}{l}\text { Standard occupational classification of } \\
\text { respondents in employment }\end{array}$ & & $\mathrm{LFS}^{\mathrm{b}}$ \\
\hline Manager (1) & 15 & 14 \\
\hline Professional (2) & 30 & 12 \\
\hline Associate (3) & 17 & 13 \\
\hline Administrative (4) & 21 & 13 \\
\hline Skilled trades (5) & 5 & 12 \\
\hline Personal service (6) & 4 & 7 \\
\hline Sales/customer (7) & 3 & 8 \\
\hline Operatives (8) & 3 & 9 \\
\hline Elementary (9) & 3 & 12 \\
\hline $\begin{array}{l}\text { 'Which of the following best describes where } \\
\text { you live?' }\end{array}$ & & $\mathrm{OPCS}^{\mathrm{c}}$ \\
\hline Remote & 5 & \\
\hline Village & 34 & \\
\hline Town & 33 & \\
\hline City suburb & 21 & \\
\hline City central & 7 & \\
\hline Remote, mainly rural & & 11 \\
\hline Mixed urban/rural and accessible rural & & 20 \\
\hline Towns & & 25 \\
\hline Metro & & 44 \\
\hline
\end{tabular}

Table 7.3 Comparison of fuel crisis sample with general population 
Travel Behaviour of Car Users During the UK Fuel Crisis 133

\begin{tabular}{lcc}
\hline Characteristic & $\begin{array}{c}\text { Fuel crisis } \\
\text { sample } \\
(\%)\end{array}$ & $\begin{array}{c}\text { General } \\
\text { pop. } \\
(\%)\end{array}$ \\
\hline $\begin{array}{l}\text { Respondent's car use } \\
\text { Car driver }\end{array}$ & 96 & NTS $^{\mathrm{d}}$ \\
$\begin{array}{l}\text { Household car but not regular driver } \\
\text { No household car }\end{array}$ & 1 & \\
& 3 & 28 \\
No. of cars in household for respondents in & & \\
household with a car & & $\mathrm{NTS}^{\mathrm{d}}$ \\
1 & 43 & 62 \\
2 & 45 & 31 \\
$>2$ & 12 & 7 \\
Annual mileage of respondent & & $\mathrm{Lex}^{\mathrm{a}}$ \\
Average & 9600 & 9300 \\
'I support government in not reducing fuel & & $\mathrm{ICM}^{\mathrm{e}}$ \\
taxes as a result of the crisis' & & \\
Agree or strongly agree & 34 & 40 \\
Disagree or strongly disagree & 57 & 55 \\
\hline
\end{tabular}

a Lex figures apply to a 1998 GB survey of 1,297 randomly selected car drivers (defined as driving at least once a month) (Lex, 1999). b LFS figures apply to UK population in employment in Spring 2001 (LFS, 2001).

c OPCS figures are percentage of population of England and Wales in 1991 living in different district types (OPCS, 1992). d NTS figures apply to GB population in 1999 (DETR, 2001: Table 1.2).

e ICM figures apply to a petrol crisis poll of 514 randomly selected adults in GB carried out on 12/09/00. The question asked was 'do you think the government should reduce the tax on petrol SPECIFICALLY in response to the protest or not?' $55 \%$ said yes, $40 \%$ said no (ICM, 2000b).

The difference in occupation type distribution was anticipated to some extent as the fuel crisis survey was aimed at car users who have a higher proportion of people in occupation types 1-4 than the general population in employment. However, the effect was more pronounced than desired and may be due to the distribution approach and differences in propensity to return questionnaires between occupation types. 
Of the fuel crisis sample, 39 per cent considered where they lived to be either a 'village' or a 'remote area'. In 1991, 31 per cent of the England and Wales population lived in a remote, mainly rural area, accessible rural area or mixed urban/rural area. The differences in definition in the two cases and the subjectivity inherent in the fuel crisis responses make comparison difficult. At face value, it appears that the fuel crisis sample is over-represented by rural dwellers and under-represented by city dwellers.

Of the fuel crisis survey sample, 96 per cent were regular car drivers. 1 per cent of the sample lived in households with a car but were not regular drivers of a car. Most of these respondents would be regular car passengers. The remaining 3 per cent of the sample lived in households without a car. Many of these will occasionally be car users and therefore were retained in the sample. In comparison to the fuel crisis survey sample, 28 per cent of the GB population live in households where they do not have a car available to them. This shows that the survey was successful in attracting car users.

Of the fuel crisis survey sample, 57 per cent who lived in a household with a car, had two or more cars while this figure is only 38 per cent for the GB population generally (difference is statistically significant at the 99.9 per cent level). The annual mileage driven by car by the fuel crisis sample respondents was very similar to that by GB motorists generally (difference is not statistically significant at the 95 per cent level).

The proportion of respondents believing that government should reduce fuel taxes as a result of the protest is similar for the fuel crisis survey sample and the general GB population (difference is not statistically significant at the 95 per cent level).

There are large differences between the socio-economic characteristics of the fuel crisis sample and the general population but the amount of car travel undertaken and attitudes to the fuel protests are similar. The main focus of the analysis of the survey data concerned the changes made by car users and the circumstances in which they were made. No attempt has been made to predict aggregate changes made during the fuel crisis or forecast future changes to car use for new transport measures. In this context, the representativeness of the sample is not a substantial concern.

\section{Results of the Fuel Crisis Survey}

In this section the results of the survey are described. First comparison is made of the number of changes made for different travel purposes and then the main types of changes are identified and examined in some detail. Reasons given for not changing car use are described before completing the results with some overall responses made to car use. 
For what travel purposes were changes made to car use?

In the second column of Table 7.4 it is shown for how many of the respondents each travel purpose is applicable. The lowest figure is for school escort travel where only 36 per cent of the sample said that they undertake this type of travel. 80 per cent of the sample said they travel to work and 54 per cent said they undertake journeys while at work. In the fourth column of table 7.4 (under 'Car users') it is shown how many of the total sample use the car for each travel purpose. This shows that the car is the main mode for all travel purposes, although for journeys to work and school escort travel many of the respondents use other modes.

Figures on changes to car use are shown both for any change to car use and any major change to car use. Major change to car use is taken to include trip reduction, trip origin or destination change, trip chaining, train, bus, cycle, walk, other vehicle and car share. The following changes have not been considered to be major changes, as they are likely to be responses particular to the fuel crisis situation, which would not occur as a consequence of transport policy measures:

- Change of route or driving style to save fuel.

- Change of route to avoid fuel protest demonstrations or petrol filling station queues.

- Rescheduled or additional trips made to stock up on food.

Referring to the master-list of types of change made to car use included at the end of the chapter the types of change not considered are those identified as belonging to groups 10 to 13 . Unless stated otherwise, in the results that follow these changes to car use have been excluded from consideration. 
136 Transport Lessons from the Fuel Tax Protests of 2000

Table 7.4 Changes to car use for different travel purposes

\begin{tabular}{|c|c|c|c|c|c|c|c|c|}
\hline \multirow[t]{2}{*}{$\begin{array}{l}\text { Travel } \\
\text { purpose }\end{array}$} & \multicolumn{2}{|c|}{$\begin{array}{l}\text { Applicable } \\
\text { purpose }\end{array}$} & \multicolumn{2}{|c|}{ Car users (A) } & \multicolumn{2}{|c|}{$\begin{array}{l}\text { Car users } \\
\text { making at } \\
\text { least one } \\
\text { change of } \\
\text { any kind }\end{array}$} & \multicolumn{2}{|c|}{$\begin{array}{c}\text { Car users } \\
\text { making at } \\
\text { least one } \\
\text { major change }\end{array}$} \\
\hline & No. & $\begin{array}{l}\% \text { of } \\
\text { total }\end{array}$ & No. & $\begin{array}{l}\% \text { of } \\
\text { total }\end{array}$ & No. & $\begin{array}{c}\% \text { of } \\
\text { A }\end{array}$ & No. & $\begin{array}{c}\% \text { of } \\
\text { A }\end{array}$ \\
\hline Commuting & 1324 & 80 & 1065 & 64 & 491 & 46 & 450 & 42 \\
\hline Business & 894 & 54 & 801 & 48 & 326 & 41 & 321 & 40 \\
\hline School & 598 & 36 & 347 & 21 & 132 & 38 & 128 & 37 \\
\hline Groceries & 1598 & 96 & 1555 & 94 & 556 & 36 & 481 & 31 \\
\hline Other* & $1659^{\mathrm{a}}$ & 100 & $1617^{\mathrm{b}}$ & 97 & 910 & 56 & 910 & 56 \\
\hline
\end{tabular}

About 40 per cent of car users for commuting, business and school escort travel made at least one major change to car use. The figure was lower for grocery shopping (31 per cent) and higher for other travel (56 per cent), which mostly comprises leisure travel.

What types of changes to car use were made?

Table 7.5 sets out the types of changes made to car use for the five different travel purposes. The types of change are mutually exclusive, ie. if two trips are chained then this is considered as trip chaining only and not trip reduction. It shows that 12 to 16 per cent of car users made fewer trips for commuting, business and grocery shopping travel and 51 per cent made fewer trips for other travel. For grocery shopping 14 per cent of car users made a trip origin or destination change. These responses involved using more local shops. In some of these cases a change of mode was also involved (usually from car to walking).

For commuting and school escort travel, substantial numbers of car users changed mode and car shared. Trip chaining, where travel for one purpose is carried out while travelling for another purpose, was only a substantial response for grocery shopping.

Table 7.5 Types of changes made to car use 
Travel Behaviour of Car Users During the UK Fuel Crisis 137

\begin{tabular}{|c|c|c|c|c|c|c|c|c|c|c|}
\hline & & & & & ravel & urpos & & & & \\
\hline & Comr & & Bus & & Scl & & Gro & & $\mathrm{Ot}$ & \\
\hline No. of car users & 10 & & & & & & & & 16 & \\
\hline Type of change & No. & $\%^{\mathrm{a}}$ & No. & $\%^{\mathrm{a}}$ & No. & $\%^{\mathrm{a}}$ & No. & $\%^{a}$ & No. & $\%$ \\
\hline Trip reduction & 126 & 12 & 246 & 16 & 15 & 4 & 216 & 14 & 826 & 51 \\
\hline Trip OD change & 26 & 2 & 8 & 1 & 1 & 0 & 210 & 14 & 39 & 2 \\
\hline Trip chaining & 12 & 1 & 13 & 2 & 6 & 2 & 75 & 5 & 18 & 1 \\
\hline Train & 59 & 6 & 19 & 2 & 0 & 0 & 0 & 0 & 14 & 1 \\
\hline Bus & 68 & 6 & 11 & 1 & 11 & 3 & 8 & 1 & 28 & 2 \\
\hline Cycle & 40 & 4 & 4 & 0 & 16 & 5 & 12 & 1 & 32 & 2 \\
\hline Walk & 30 & 3 & 13 & 2 & 73 & 21 & 24 & 2 & 68 & 4 \\
\hline Car share & 123 & 12 & 16 & 2 & 14 & 4 & 8 & 1 & 46 & 3 \\
\hline Other vehicle & 31 & 3 & 5 & 1 & 9 & 3 & 11 & 1 & 0 & - \\
\hline Total $^{\mathrm{c}}$ & 515 & - & 335 & - & 145 & - & 564 & - & 1071 & - \\
\hline Driving style $^{\mathrm{d}}$ & 54 & 5 & 7 & 1 & 5 & 1 & 2 & 0 & - & - \\
\hline Trip increase & 0 & 0 & 0 & 0 & 0 & 0 & 50 & 3 & 0 & 0 \\
\hline Trip rescheduling ${ }^{\mathrm{e}}$ & 0 & 0 & 0 & 0 & 0 & 0 & 49 & 3 & 0 & 0 \\
\hline Total $^{\mathrm{C}}$ & 569 & - & 343 & - & 150 & - & 665 & - & 1071 & - \\
\hline
\end{tabular}

a Percentage of car users (number of car users is noted above).

b Trip origin or destination change.

c Some respondents made more than one type of change for the same travel purpose, therefore no figure is given for total percentage.

This also explains why the total number of changes for each travel purpose is greater in Table 7.5 than Table 7.4.

d Changes to driving style not noted for other travel.

e Rescheduling trip for earlier in week.

Care must be taken when comparing responses made between travel purposes. The viability of responses depends on the travel purpose. For most parents and guardians, trip reduction is not a viable choice for school escort travel, unless there is no means to get the children to school. Changing the origin or destination is unlikely to be feasible for commuting and school escort travel. It needs to be recognised that the choice alternatives vary according to travel purpose as well as the circumstances and attitudes of an individual respondent.

Changes to car use made by a substantial number of respondents merit more detailed analysis. The following types of change are identified. 
- Commuting: trip reduction (in particular working form home), train, bus, cycling, walking and car sharing.

- Business travel: trip reduction.

- School escort travel: walking.

- Grocery shopping travel: trip reduction, trip origin-destination change (in particular walking to local shops and driving to local shops) and trip chaining.

- Other travel: trip reduction and walking.

What were the circumstances and experiences of the main changes made for commuting?

Table 7.6 sets out details of the characteristics and experiences of the respondents making the six types of changes to commuting identified above. Only a selection of what appear to be the most interesting characteristics is shown.

In some cases the number of respondents making changes varies slightly from those given in Table 7.5. To avoid double counting in Table 7.5, a change was only counted under one category, even if it involved a mixture of modes. For example, changing from car to use a combination of bus and train was considered only as a change to train. In Table 7.6 the same change is counted under both train and bus, so that attention is paid to all usage of the modes during the fuel crisis.

Table 7.6 indicates the following associations between the changes made and the characteristics of respondents.

- Working from home: manager/professional and long commute (average of 27 miles).

- Train: male, long commute (average of 23 miles) and West Yorkshire respondent.

- Bus: low car availability, short commute (average of 12 miles), West Yorkshire respondent and low on fuel at start of fuel crisis.

- Cycling: male, short commute (average of 9 miles) and admit to use car more than necessary.

- Walking: low car availability, short commute (average of 5 miles), live in town or city, low on fuel at start of fuel crisis and admit to use car more than necessary.

- Car sharing: young respondent and short commute (average of 13 miles). 
The associations tell us something about the circumstances in which the different responses were made, although further statistical analysis is required to better understand the relationships between the data. The high proportion of West Yorkshire respondents that used public transport is interesting. This may be due to the West Yorkshire Metropolitan area having a better developed public transport network than the other areas surveyed. Incidentally, the proportion of respondents in Southampton and Leicester (two medium-sized cities) using public transport instead of the car was not higher than average.

64 per cent of respondents who switched to train or bus mentioned that they sought public transport information during the fuel crisis. Only 19 per cent of all survey respondents said they sought public transport information. About half of respondents who used the train or bus, or cycled or walked had done so previously in the last six months. The proportion was lower for working from home and car sharing. For each of the six types of change to car use more than 40 per cent of respondents said they would consider using the option again in future. The proportion was highest for cycling and walking. Working from home tended to only occur for one day, whilst about half of those changing from car use to using the train, cycling, walking or car sharing made the change for at least two days during the fuel crisis week.

Working from home was not always a practice that fitted well with respondents' occupations:

Cannot do my job without access to the people in many different locations that are impractical for public transport. (\#1074) 
140 Transport Lessons from the Fuel Tax Protests of 2000

Table 7.6 Characteristics and experiences of respondents making change to car commuting

\begin{tabular}{|c|c|c|c|c|c|c|c|}
\hline Change & $\begin{array}{c}\text { All } \\
\text { car } \\
\text { users }\end{array}$ & $\begin{array}{l}\text { Work } \\
\text { from } \\
\text { home }\end{array}$ & Train & Bus & Cycle & Walk & $\begin{array}{l}\text { Car } \\
\text { share }\end{array}$ \\
\hline $\begin{array}{l}\text { No. respondents } \\
\text { (A) }\end{array}$ & 1,065 & 67 & 59 & 81 & 43 & 31 & 123 \\
\hline \multicolumn{8}{|l|}{ Characteristics } \\
\hline Mean age & 43 & 43 & 43 & 43 & 43 & 43 & 41 \\
\hline $\begin{array}{l}\text { Mean } \\
\text { cars/household }\end{array}$ & 1.9 & 1.9 & 1.7 & 1.6 & 1.8 & 1.5 & 1.8 \\
\hline \multirow{2}{*}{$\begin{array}{l}\text { Mean commute } \\
\text { length in miles }\end{array}$} & 15 & 27 & 23 & 12 & 9 & 5 & 13 \\
\hline & \multicolumn{7}{|c|}{ Figures below are per cent of respondents (A) } \\
\hline Male respondent & 50 & 55 & 66 & 49 & 60 & 23 & 45 \\
\hline $\begin{array}{l}\text { W. Yorkshire } \\
\text { respondent }\end{array}$ & 28 & 28 & 47 & 57 & 14 & 29 & 37 \\
\hline $\begin{array}{l}\text { Manager or } \\
\text { professional }\end{array}$ & 44 & 66 & 53 & 37 & 44 & 39 & 49 \\
\hline $\begin{array}{l}\text { Live in remote } \\
\text { area or village }\end{array}$ & 40 & 42 & 32 & 31 & 35 & 26 & 41 \\
\hline $\begin{array}{l}\text { At least half tank } \\
\text { at start of crisis }\end{array}$ & 84 & 75 & 73 & 63 & 74 & 65 & 74 \\
\hline $\begin{array}{l}\text { Admit to use car } \\
\text { more than } \\
\text { necessary }\end{array}$ & 25 & 31 & 27 & 26 & 40 & 45 & 29 \\
\hline $\begin{array}{l}\text { Sought public } \\
\text { transport info } \\
\text { during fuel crisis }\end{array}$ & 22 & 43 & 64 & 64 & 21 & 32 & 22 \\
\hline
\end{tabular}


Travel Behaviour of Car Users During the UK Fuel Crisis 141

Table 7.6 Characteristics and experiences of respondents making change to car commuting

\begin{tabular}{lccccccc}
\hline Change & $\begin{array}{c}\text { All } \\
\text { car } \\
\text { users }\end{array}$ & $\begin{array}{c}\text { Work } \\
\text { from } \\
\text { home }\end{array}$ & Train & Bus & Cycle & Walk & $\begin{array}{c}\text { Car } \\
\text { share }\end{array}$ \\
\hline $\begin{array}{l}\text { No. respondents } \\
\text { (A) }\end{array}$ & 1,065 & 67 & 59 & 81 & 43 & 31 & 123 \\
\hline
\end{tabular}

Figures below are per cent of respondents (A)

\begin{tabular}{|c|c|c|c|c|c|c|c|}
\hline \multicolumn{8}{|l|}{ Experiences } \\
\hline $\begin{array}{l}\text { Use car or this } \\
\text { option anyway } \\
\text { but increased use }\end{array}$ & - & 6 & 2 & 10 & 14 & 19 & 3 \\
\hline $\begin{array}{l}\text { Changed on } 1 \\
\text { day only }\end{array}$ & - & 57 & 37 & 38 & 27 & 10 & 30 \\
\hline $\begin{array}{l}\text { Changed on 2+ } \\
\text { days }\end{array}$ & - & 33 & 46 & 38 & 50 & 52 & 45 \\
\hline $\begin{array}{l}\text { Used option in } \\
\text { last } 6 \text { months }\end{array}$ & - & 34 & 46 & 38 & 47 & 55 & 29 \\
\hline $\begin{array}{l}\text { Willing to use } \\
\text { option again in } \\
\text { future }\end{array}$ & - & 42 & 53 & 42 & 67 & 68 & 47 \\
\hline \multicolumn{8}{|l|}{$\begin{array}{l}\text { Reason for not } \\
\text { using option } \\
\text { again }\end{array}$} \\
\hline Cost & - & 0 & 9 & 21 & 2 & 3 & 2 \\
\hline Time & - & 1 & 17 & 18 & 0 & 6 & 4 \\
\hline Tiring & - & 0 & 3 & 2 & 11 & 3 & 0 \\
\hline Use car at work & - & 0 & 6 & 8 & 9 & 6 & 2 \\
\hline Loss of income & - & 0 & 0 & 1 & 0 & 0 & 1 \\
\hline Impact on work & - & 12 & 2 & 2 & 5 & 3 & 1 \\
\hline Lost flexibility & - & 1 & 8 & 2 & 0 & 3 & 42 \\
\hline \multicolumn{8}{|l|}{$\begin{array}{l}\text { Reason for using } \\
\text { option again }\end{array}$} \\
\hline Health/fitness & - & 0 & 0 & 4 & 16 & 10 & 0 \\
\hline Enjoyable & - & 0 & 3 & 0 & 23 & 13 & 3 \\
\hline
\end{tabular}


142 Transport Lessons from the Fuel Tax Protests of 2000

Cost and time were often cited as a reason for not continuing to use public transport in the future.

Needed to save fuel to ensure enough for appointment in Hull... Takes too long to travel. Uncertain of reliability of railways. Too expensive. (\#1522)

Only if I wasn’t rushing to get home or didn't have off-site meetings, etc or shopping to do! (\#1095)

The health benefits and enjoyment of cycling and walking were often mentioned as positive reasons to cycle again in future. The loss of flexibility in car share arrangements was mentioned by nearly half of those who car shared as a problem for future use of this option.

I enjoyed the company on the journey. Would save fuel money. It would not however be possible every day due to work/personal commitments. (\#831)

In processing the survey information it was also noted when a respondent mentioned that they vary their travel option and do not have a single way of getting to work that they use every day. Table 7.6 indicates the percentage of respondents who said they sometimes use the alternative anyway and during the fuel crisis week increased their use of it. For train 2 per cent (one out of the 63 respondents) said they sometimes use the train anyway. For the other travel alternatives the values were higher. For walking it was 19 per cent.

It is important to recognise there is variation in the character of the responses made within the six general categories examined above. Taking the example of train, Table 7.7 is a turnover table showing the precise details of the usual commuting mode and the response made. Only 24 of the 63 changes made were from car driving alone to train with 34 of the 63 changes made from car driving to train combined with another mode. Turnover tables are a useful means of describing changes of mode usage between two periods of time (Chatterjee, 2001). In this case the behaviour of people who usually use the train and other non-car modes has not been surveyed, so a full turnover table is not able to be presented. Thorpe et al. (2002: Table 8.3) present a full turnover table for journeys to work/college/school before and during the fuel crisis. 
Travel Behaviour of Car Users During the UK Fuel Crisis 143

Table 7.7 Turnover table for respondents using train

\begin{tabular}{lccccc}
\hline Change & Train & $\begin{array}{c}\text { Bus \& } \\
\text { train }\end{array}$ & $\begin{array}{c}\text { Walk/ } \\
\text { cycle \& } \\
\text { train }\end{array}$ & $\begin{array}{c}\text { Car \& } \\
\text { train }\end{array}$ & Total \\
\hline Car alone & 24 & 8 & 14 & 12 & 58 \\
$\begin{array}{l}\text { Car with } \\
\text { passenger } \\
\begin{array}{l}\text { Car alone and } \\
\text { train }\end{array}\end{array}$ & 1 & 1 & 0 & 0 & 2 \\
$\begin{array}{l}\text { Car as passenger } \\
\text { Total }\end{array}$ & 1 & 0 & 0 & 0 & 1 \\
\hline
\end{tabular}

What were the circumstances and experiences of the main changes made for business travel?

Trip reduction was the main change to car use that occurred for business travel, accounting for 74 per cent of changes made. It involved cancellations and postponements which are likely only to be acceptable responses to a crisis situation. This is borne out by the fact that only 5 per cent of respondents who made a trip reduction response said they had done the same previously in the last six months and only 17 per cent said they would consider the same option again in future. There was no evidence of particular types of business travel (e.g. meetings, visits to clients, collections and deliveries) being targeted for trip reduction during the fuel crisis.

What were the circumstances and experiences of the main changes made for school escort travel?

Table 7.8 sets out details of the characteristics and experiences of the respondents whose children walked to school instead of using the car. These respondents had shorter journey lengths, although the average was still 1.8 miles. They were less likely to live in a rural area, have older children only, have children at more than one school and be in a car share 
arrangement. They were more likely to admit to use their car more than necessary (47 per cent compared to 37 per cent for all respondents who use the car for school escort travel).

Table 7.8 Characteristics and experiences of respondents whose children walked to school instead of going by car

\begin{tabular}{|c|c|c|}
\hline Change & All car users & Walk \\
\hline No. respondents (A) & 347 & 73 \\
\hline \multicolumn{3}{|l|}{ Characteristics } \\
\hline \multirow{2}{*}{ Mean journey length in miles } & 4.1 & 1.8 \\
\hline & \multicolumn{2}{|c|}{$\begin{array}{l}\text { Figures below are per cent of } \\
\text { respondents (A) }\end{array}$} \\
\hline Household with older children only & 11 & 5 \\
\hline Live in remote area or village & 39 & 27 \\
\hline Car share arrangement for school journeys & 18 & 7 \\
\hline Have children at more than one school & 31 & 26 \\
\hline At least half tank at start of crisis & 84 & 78 \\
\hline Admit to use car more than necessary & 37 & 47 \\
\hline \multicolumn{3}{|l|}{ Experiences } \\
\hline Changed on 1 day only & - & 16 \\
\hline Changed on $2+$ days & - & 58 \\
\hline Used option in last 6 months & - & 36 \\
\hline Willing to use option again & - & 52 \\
\hline \multicolumn{3}{|l|}{ Reason for not using option again } \\
\hline Time & - & 11 \\
\hline Tiring & - & 8 \\
\hline Safety & - & 4 \\
\hline Weather & - & 14 \\
\hline Disruption to other activities & - & 4 \\
\hline \multicolumn{3}{|l|}{ Reason for using option again } \\
\hline Health/fitness & - & 4 \\
\hline Enjoyable & - & 5 \\
\hline
\end{tabular}

36 per cent of respondents whose children walked to school had done so previously in the last six months and 52 per cent said they would consider this option again in future. Most made the change for at least two days during the fuel crisis (58 per cent). 
The weather was mentioned as a factor influencing future decisions to walk by 14 per cent:

When my wife and children are sufficiently organised they walk - except when weather inclement or large quantities of books/musical instruments/games kit etc. (\#1091)

Positive aspects were mentioned by some respondents:

After the initial complaints, my eldest daughter seems to enjoy walking with her friends, but we still have reservations about safety. (\#520)

It is good to encourage the children to be independent in this way. (\#618)

What were the circumstances and experiences of the main changes made for groceries travel?

Table 7.9 sets out details of the characteristics and experiences of the respondents who walked to local shops, drove more locally or trip chained for the groceries shopping as a change to their usual use of the car. Trip reduction has not been considered, as it involved postponing grocery shopping and managing with provisions at home which is likely only to be an acceptable response to a crisis situation.

Table 7.9 indicates the following associations between the changes made and the characteristics of respondents.

- Walking to local shops: low weekly mileage and short distance for small groceries journeys.

- Driving to local shops: low weekly mileage, long distance for large groceries journeys and household with children under 16.

- Trip chaining: long distance for small groceries journeys, live in rural area and admit to use car more than necessary. 
146 Transport Lessons from the Fuel Tax Protests of 2000

Table 7.9 Characteristics and experiences of respondents making change to groceries shopping car travel

\begin{tabular}{|c|c|c|c|c|}
\hline Change & $\begin{array}{l}\text { All car } \\
\text { users }\end{array}$ & $\begin{array}{c}\text { Walk to } \\
\text { local shops }\end{array}$ & $\begin{array}{c}\text { Drive to } \\
\text { local shops }\end{array}$ & $\begin{array}{l}\text { Trip } \\
\text { chaining }\end{array}$ \\
\hline No. respondents (A) & 1555 & 120 & 55 & 75 \\
\hline \multicolumn{5}{|l|}{ Characteristics } \\
\hline Mean weekly car miles & 190 & 160 & 160 & 190 \\
\hline $\begin{array}{l}\text { Mean journey length in } \\
\text { miles for large groceries }\end{array}$ & 5.2 & 5.3 & 8.7 & 5.2 \\
\hline \multirow{2}{*}{$\begin{array}{l}\text { Mean journey length in } \\
\text { miles for small groceries }\end{array}$} & 2.4 & 1.5 & 2.7 & 3.0 \\
\hline & \multicolumn{4}{|c|}{ Figures below are per cent of respondents (A) } \\
\hline $\begin{array}{l}\text { Live in remote area or } \\
\text { village }\end{array}$ & 40 & 34 & 44 & 48 \\
\hline $\begin{array}{l}\text { Household with children } \\
\text { under } 16\end{array}$ & 37 & 38 & 45 & 43 \\
\hline $\begin{array}{l}\text { At least half tank at start } \\
\text { of crisis }\end{array}$ & 84 & 76 & 78 & 81 \\
\hline $\begin{array}{l}\text { Admit to use car more } \\
\text { than necessary }\end{array}$ & 26 & 28 & 25 & 37 \\
\hline \multicolumn{5}{|l|}{ Experiences } \\
\hline Changed on 1 day only & - & 12 & 20 & 59 \\
\hline Changed on $2+$ days & - & 39 & 20 & 11 \\
\hline $\begin{array}{l}\text { Used option in last } 6 \\
\text { months }\end{array}$ & - & 10 & 15 & 19 \\
\hline $\begin{array}{l}\text { Willing to use option } \\
\text { again }\end{array}$ & - & 22 & 25 & 27 \\
\hline \multicolumn{5}{|l|}{$\begin{array}{l}\text { Reason for not using } \\
\text { option again }\end{array}$} \\
\hline Cost & & 17 & 16 & 3 \\
\hline Time & - & 11 & 5 & 4 \\
\hline Bulky items & - & 8 & 2 & 1 \\
\hline Lack of choice & - & 9 & 20 & 4 \\
\hline
\end{tabular}


Fewer than 20 per cent of the respondents making each of these changes to car use had done so previously in the last six months and fewer than 30 per cent said they would consider using the option again in future. 39 per cent of those who walked to local shops did so at least twice.

Expense, time taken, difficulty carrying items and lack of choice were regularly mentioned as reasons for not wishing to use local shops again in the future:

Not so much choice at local for all of our groceries plus things are more expensive. I do support local shops for basic items however. (\#6)

The bags were heavier by the time I reached home than when I bought them. The car is the answer. (\#951)

Positive aspects were mentioned by a few respondents:

Shopping in this way would not be a great inconvenience as reasonable shops - choice and prices - locally within 1 mile. (\#559)

What were the circumstances and experiences of the main changes made for other types of travel?

The survey asked respondents to give details of changes made to other travel planned (prior to the crisis) to be made by car during the fuel crisis. As with business travel, trip reduction was the main change, accounting for 83 per cent of changes made. There were 1,442 mentions of trips not being made which equates to nearly one mention for each respondent. Trip reduction involved cancellations (77 per cent) postponements (12 per cent), phoning instead (5 per cent) and making fewer journeys (5 per cent). In most of these instances not making the journey is likely only to be an acceptable response during a crisis situation. There were also 81 mentions of walking instead of using the car.

Respondents were asked to describe the purpose of other travel affected by the fuel crisis. The main purposes mentioned were social/entertainment (46 per cent), visits to friends (38 per cent), shopping other than groceries (8 per cent) and holidays/day trips (4 per cent). Examination was made to see whether the responses varied according to travel purpose. Visits to the cinema were more likely to be cancelled than other travel purposes. Visits to friends were more likely to be postponed, substituted by a phone call or made on fewer occasions than other travel purposes. 


\section{What reasons were given for not changing car use?}

Table 7.10 identifies the reasons given for not making a change to car use. Reasons were noted (where mentioned by respondent) for all respondents not making any change to car use. The most common reason for not making a change was having sufficient fuel. This is an expected result given that 71 per cent of the GB population with a car available to them said they did not run so low on petrol they had to stop using their car (ICMa, 2000). It is interesting to note that 13 per cent of commuting car users made no change because they were on leave and 31 per cent of business travel car users made no change because they had no journey to make. Only small numbers mentioned that the inadequacy of other modes was the reason for not making any change.

Table 7.10 Primary reason given for not changing car use

\begin{tabular}{lcccc}
\hline \multicolumn{1}{c}{ Travel purpose } & Commuting & Business & School & Groceries \\
\hline $\begin{array}{l}\text { No. respondents } \\
\text { not making any } \\
\text { change (A) }\end{array}$ & 574 & 475 & 215 & 999 \\
\hline Reason & \multicolumn{4}{c}{ Figures below are per cent of respondents (A) } \\
\hline $\begin{array}{l}\text { Away from } \\
\text { work/school }\end{array}$ & 13 & 7 & 2 & 3 \\
$\begin{array}{l}\text { Enough fuel } \\
\begin{array}{l}\text { No journey } \\
\text { needed }\end{array}\end{array}$ & 1 & 20 & 47 & 33 \\
$\begin{array}{l}\text { Linked to other } \\
\text { trip } \begin{array}{l}\text { Other modes } \\
\text { unacceptable }\end{array}\end{array}$ & 1 & 31 & 0 & 14 \\
\begin{tabular}{l} 
Other reason \\
\hline
\end{tabular} & 7 & 0 & 7 & 7 \\
\hline
\end{tabular}

How many changes did respondents make to car use?

Figure 7.1 shows for how many of the five travel purposes (commuting, business, school, groceries and other) a major change to car use was made. 
Only a quarter of the respondents made no change and 42 per cent made at least two changes. The number of travel purposes that were applicable to a respondent varied from zero to five. Only 144 respondents noted that they normally use the car for all five travel purposes.

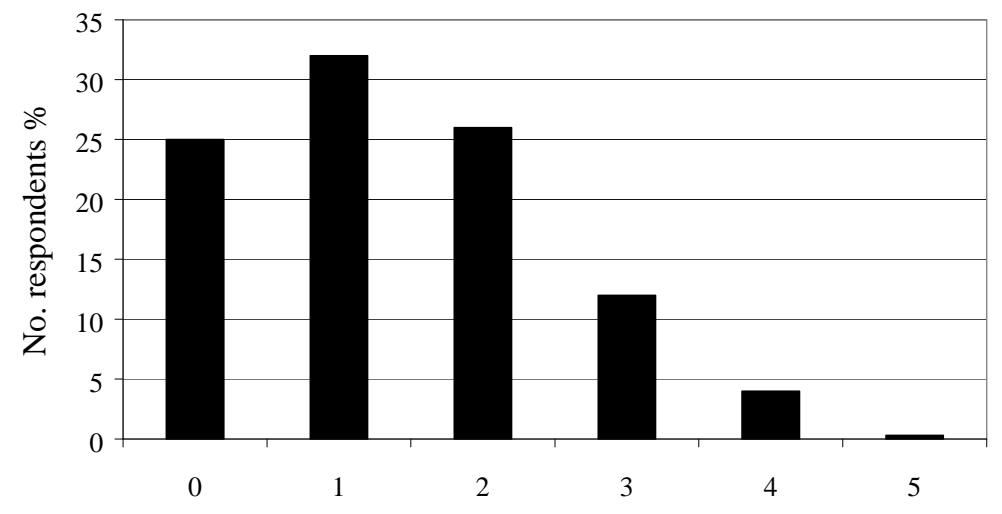

No. of travel purposes changed during the crisis

Figure 7.1 Number of travel purposes changed during crisis

How did changes to car use depend on combinations of travel purposes?

Those respondents who use the car for more types of travel might be expected to make changes to a greater proportion of them to conserve fuel. Table 7.11 looks at the most common four combinations of applicable travel purposes (which account for 76 per cent of the survey respondents). The expected numbers of changes in Table 7.11 are calculated based on the average percentage of respondents making a major change to each travel purpose in Table 7.4. Table 7.11 suggests that respondents using the car for four or five travel purposes made about the same proportion of changes as those using the car for two or three purposes.

Table 7.11 Number of purposes of travel changed

\begin{tabular}{cccc} 
Applicable travel purposes & $\begin{array}{c}\text { No. of } \\
\text { respondents }\end{array}$ & $\begin{array}{c}\text { Expected } \\
\text { number of }\end{array}$ & $\begin{array}{c}\text { Actual } \\
\text { number of }\end{array}$ \\
\hline
\end{tabular}


150 Transport Lessons from the Fuel Tax Protests of 2000

\begin{tabular}{lccc}
\hline & & changes & changes \\
\hline G, O & 329 & 286 & 276 \\
C, G, O & 291 & 375 & 377 \\
C, B, G, O & 490 & 828 & 856 \\
C, B, S, G, O & 144 & 297 & 303 \\
\hline C = commuting, B = business, S = school escort, G = groceries, O = other & & \\
\hline
\end{tabular}

Examination of the travel purposes changed for the respondents with the four combinations in Table 7.11 shows that those with the combinations of five (C, B, S, G, O) and four (C, B, G, O) applicable travel purposes made more changes to other travel. Most other travel is for leisure purposes which suggests that leisure travel was given lower priority and modified (mostly through foregoing the activity) to enable other travel to take place.

The four combinations above have also been analysed to see whether within them there are greater than expected numbers of 'flexible' car users (who made many changes) and 'inflexible' car users (who made few or no changes) than would be expected if every respondent had an equal probability of making a change to each travel purpose. The expected numbers of changes were again calculated based on the average percentage of respondents making a major change to each travel purpose in Table 7.4. The analysis, indeed, showed that there are 'flexible' and 'inflexible' car users. There are many possible reasons for this, including the likelihood that some respondents had more amenable circumstances than others to make changes (for example, more alternative modes and local services) and some respondents had more available vehicles and fuel. There will also have been differences in attitudes towards the need to make any change to car use.

An understanding has been gained of the circumstances and experiences surrounding the main types of changes to car use that occurred during the fuel crisis. Statistical analyses (eg. correlations, regression models) may be helpful in exploring further the relationships within the data. The survey should prove to be a valuable resource of information for future travel behaviour analysis.

\section{Discussion of the Results}

\section{Conditions during the Fuel Crisis}

Before drawing conclusions regarding the implications of the survey results it is important to consider the nature of the situation faced by car users 
during the fuel crisis and how this relates to the conditions that they may experience in future. In effect the fuel crisis wielded a stick of unprecedented size against car use. At the same time the carrot of alternatives to the car did not change. It may have even got smaller in size because of service disruptions. In fact, Thorpe et al. (2002: Table 8.3) note in Chapter 8 that a small number of travellers switched from public transport to car during the fuel crisis. It is unlikely that any government would itself wield such a big stick in policy terms. Nevertheless, in the UK the stick against car use will increase in size with the introduction of policies such as road user charging. The government's ten year plan should increase the size of the carrot in terms of the availability and quality of alternatives to the car. So, the carrot and stick during the fuel crisis are of different size to those that exist normally or that might exist in future.

Another point to bear in mind is that conditions during the fuel crisis varied across the country and between individuals. In practice different parts of the UK suffered different levels of fuel shortage at different times and some individuals secured ample fuel for their immediate requirements, whilst others had little or none. Individuals would also have had different perceptions of the likely duration and severity of the situation.

There is perhaps an added complication. During the fuel crisis everyone faced an environment of fuel shortage and restrictions on car use. It is likely as a consequence that social norms were temporarily adjusted. Social norms are people's beliefs about the attitudes and behaviours that are normal, acceptable, or even expected in a particular social context. In many situations, people's perception of these norms will greatly influence their behaviour. During the fuel crisis it is likely that it became perceived amongst car users as much more acceptable to use other forms of transport. Travelling by bus may have not been considered a loss of social status during the fuel crisis because other people were having to use it. The survey showed for commuting that many respondents were happy to car share during the fuel crisis, although they would not wish to do so afterwards. When the crisis ended it is assumed that temporary distortions of social norms more or less disappeared.

\section{Responses during the Fuel Crisis}

The next question to ask is whether the circumstances of the fuel crisis will have produced responses of a similar magnitude and character as that which can be expected for future transport policy scenarios. An important 
characteristic of the fuel crisis is that there was no time for people to plan their responses to the circumstances created by the crisis or to adapt over time. Car users had to make tactical decisions on how to conserve fuel, whereas in response to policy measures they would be able to make strategic decisions. (This is discussed further in Chapter 14 (Bonsall, 2002)). In Section 6 of the survey it was asked whether respondents would reduce the number of car trips they make, move house to be nearer regular activities or buy a more efficient vehicle if fuel was rationed on a continuous basis. 84 per cent said they would reduce car trips, 12 per cent said they would buy a more efficient vehicle and 4 per cent said they would move house. At face value, this suggests that most car users would not make long term changes and would instead make fewer trips by car.

There is a case to argue that the fuel crisis survey results represent a realistic indication of how car users would respond to policy measures promoting alternatives to the car and restricting car use. First, it should be reiterated that the survey captured actual responses to a real situation, unlike many surveys which obtain stated responses to a hypothetical situation. Second, those able to make changes to their car use, especially where they continued with their planned activity, were able to do so without much advance preparation. This indicates that their responses are feasible generally. Third, it has also been remarked previously that changes made during the fuel crisis had often been mentioned by respondents to have been made previously and as such are rehearsed alternatives.

Given the lack of time for car users to prepare responses to the fuel crisis it might even be argued that more substantial changes to car use would occur in future policy scenarios. There would be more time to examine alternative modes and destinations nearer to home. On the other hand, the trips cancelled in a crisis situation are unlikely to be dealt with in the same way in future policy scenarios. Other responses would be made, many of which would involve car use.

Having made these points, the large size of the stick on car use that existed during the fuel crisis has to be appreciated. The fuel crisis survey results are only likely to be indicative of policy scenarios which feature substantial restrictions on car use (e.g. road user charging).

\section{Impacts of Car Reduction during Fuel Crisis}

The following factors need to be considered when attempting to estimate the impacts on aggregate car travel of the changes made during the fuel crisis. 
- Frequency change made: it has been noted in the survey whether changes were made on one occasion or more. Working from home was generally only carried out on one day, whilst children walking to school was generally carried out on at least two days.

- Car travel remains involved in some changes: for car sharing typically one car journey is removed for every two car sharing trips. Table 7.7 shows that train was used in combination with car (park and ride) in one-fifth of the instances train was used instead of car for the journey to work.

- Travel distance: for trip chaining the car is still used but there is usually a reduction in distance travelled and 'cold' starts.

Taking the example of school escort travel, about one-fifth of car users made their children walk to school. These respondents had an average journey length of 1.8 miles (see Table 7.8). Assuming the journey is not trip chained and they each did this for two days of the week they reduced their car travel by 7.2 miles each. For all school escort car users in the survey sample the average weekly mileage is 41 miles. The reduction of school escort car travel for the fuel crisis sample is calculated to be 4 per cent in terms of distance and 8 per cent in terms of trips. Table 7.1 shows that school escort car accounts for 4 per cent of all GB car trips and 2 per cent of all GB car distance travelled. The impact of this fuel crisis response is quite small at an aggregate level, although that it not to say that it is negligible or not important in other respects.

\section{Insights on Car Dependence}

The survey results have yielded insight regarding the character of car trips that are most amenable to change - those trips which have been labelled as marginal in a report on car dependence (Goodwin, 1995). The proportion of trips mentioned in that report (20 per cent) appears a reasonable estimate of the amount of car travel that can be categorised in this way.

The results indicate that alternative modes are presently viable for many people who usually use the car for commuting and school travel and indicate some aspects of these alternatives that need to be addressed to increase their use. For public transport, cost and travel time are the most important issues cited by respondents. Measures that reduce the 
inflexibility problems of car sharing will be needed to increase its use. Walking and cycling are recognised to be positive options but practical concerns (weather, carrying bulky items) are a barrier for their regular use. The use of local shops is hampered by the cost of products that they offer. Many of these findings are not new but they serve to reinforce existing strategies with hard evidence. The fact that some of the changes to car use are difficult to sustain on a regular basis (e.g. cycling, car sharing) should not discourage efforts to bring them about. People have more varied lifestyles than they used to and achieving change will require addressing many different options.

Comparison with other studies shows some consistency of results. G•rling et al. (2000) looked at the car use reduction measures perceived to be feasible by households in Gothenburg, Sweden. For commuting, public transport was the most likely choice. Closer destinations and trip chaining were identified for shopping and leisure trips. Kingham et al. (2001) examined what factors would influence employees in Hertfordshire to reduce car commuting and found potential for increased cycling and use of public transport if improvements in infrastructure and services were made. Mackett (2000) looked at measures required to reduce use of the car for journeys less than five miles. The survey sample were households in five areas of England. School escort journeys had the most potential for change. Of all short car trips, a switch to walking could be made for 31 per cent, to using the bus made for 31 per cent and to cycling made for 7 per cent. The measure that would have most impact on car use was found to be improving bus services.

The fuel crisis survey results also provide clear evidence that a majority of car travel at present is not considered to be viable to undertake by alternative means. Very little business and leisure travel was changed in any way other than simply not being undertaken. Table 7.1 indicates that leisure, business and other personal and escort travel accounts for 54 per cent of car trips and 65 per cent of all car distance travelled. Solutions to reducing car travel of this kind require efforts not only in transport but in land use planning and other policy areas.

Some survey respondents discussed how the fuel crisis had triggered them into considering sustained changes in travel behaviour:

I bought a monthly season ticket...and intend using public transport from now on... Commuting by car from West Manchester to Halifax although usually fast is often stressful. Also driving with one person in the car is wasteful. (\#602) 
Will use bus one day (a week). Work schedule changing and that will mean bus is more convenient than car. Might use bus another day if I find buses run to time ok. (\#1605)

This has hastened my arrangements to be able to work electronically from home more, which were being pushed by the rise in petrol price anyway. It's also given me more incentive to find another job nearer home, so I'm looking more seriously. (\#1591)

These quotes highlight how events in people's lives, whether they are on a scale like the fuel crisis or personal events such as a new job, provide opportunities to reassess behaviour. Transport policy strategies should be developed acknowledging the opportunity of these occasions for creating behavioural change. The existence of these opportunities also brings some optimism to the prospects of bringing about change, as explained below:

I would say that the only successful pathway to substantial change in transport behaviour at the aggregate level is by intervening to secure an 'asymmetric pattern of churn'. It means that we should stop talking in terms of encouraging people to stop driving and start using public transport - but seeking to increase a little the numbers of people who are already, every year, doing exactly that in huge numbers, and reducing a little the numbers of people who are already, every year, doing exactly the opposite, in equally huge numbers. (Goodwin, 1999) 
156 Transport Lessons from the Fuel Tax Protests of 2000

\section{Conclusions}

The fuel crisis survey has shown that three-quarters of car users made a change to their car use during the fuel crisis. A lot of leisure, business and shopping travel was not undertaken. 31 per cent of commuting car users changed mode or car shared. 14 per cent of grocery shopping car users shopped more locally than usual, either going by car or walking or cycling.

Consideration of the special circumstances of the fuel crisis suggests the following. Where car use was reduced by not travelling this is not likely to be repeated in any future policy scenario. Where car use was reduced by using alternative modes or travelling shorter distances this gives a good indication of the absolute level of response and relative levels of response that would occur in a future scenario where transport policy acts mainly to restrict car use. The fuel crisis results, however, tell us less about the likely responses to policy that improves alternatives to the car.

The survey results provide reinforced evidence on areas fruitful to target in reducing car travel. These include fast and affordable public transport for journeys to work, car sharing and work from home programmes, school walking and cycling programmes and planning policy to promote affordable local food shops. The results also show that the majority of car travel is not amenable to change in the short term and will require sustained policy initiatives in transport and other policy areas if it is to be reduced. Policy action is required on two fronts: short term action to target marginal car travel and long term action to target entrenched car travel.

Events like the fuel crisis can not only reveal insight into behaviour but can trigger change. Very little of the change to car use that took place during the fuel crisis was probably sustained afterwards by those making it. This is not to say that events of various kinds should not be taken seriously as a means of influencing change. Finally, it should be remembered that bringing about change to a relatively small proportion of car use can make a substantial difference to congestion, pollution and other aspects of the quality of our lives.

\section{References}

Bhat, C.R. and Koppelman, F. S. (2000). Activity-Based Travel Demand Analysis: History, Results and Future Directions, Preprint of paper presented at 79th Annual Meeting of Transportation Research Board, Washington, D.C., 9-13 January.

Bonsall, P. (2002). What Can be Learned from Studying Transport Crises? In Lyons, G. and Chatterjee, K. (eds.) Transport Lessons from the Fuel Tax Protests of 2000, Ashgate, Aldershot. 
Chatterjee, K. (2001). Asymmetric churn - academic jargon or a serious issue for transport planning? Paper prepared for Transport Planning Society.

DETR (2000). Transport 2010 - The 10 Year Plan. Department of the Environment, Transport and the Regions, TSO, London.

DETR (2001). Transport Trends: 2001 Edition. Department of the Environment, Transport and the Regions, TSO, London.

G•rling, T., G·rling, A. and Johansson, A. (2000). Household choices of car-use reduction measures. Transportation Research Part A 34(5), 309-320.

Goodwin, P. (ed) (1995). Car Dependence. RAC Foundation for Motoring and the Environment, London.

Goodwin, P. (1999). Action or Inertia? One Year on from 'A New Deal for Transport'. Transcript of Lecture given at Transport Planning Society Meeting at the Institution of Civil Engineers, 22 July 1999.

ICM (2000a). The Guardian/ICM Monthly Poll - September 2000. Available at: http://www.icmresearch.co.uk/reviews/2000/guardian-poll-sept-2000.htm. [accessed 27/09/01]

ICM (2000b). BBC petrol crisis poll - September 2000. Available at: http://www.icmresearch.co.uk/reviews/2000/pertol-poll-september-2000.htm. [accessed 27/09/01].

Jones, P.M., Dix, M.C., Clarke, M.I. and Heggie, I.G. (1983). Understanding Travel Behaviour, Gower, Aldershot.

Kingham, S., Dickinson, J. and Copsey, S. (2001). Travelling to work: will people move out of their cars. Transport Policy 8(2), 151-160.

LFS (2001). SOC 2000 and NS-SEC on the Labour Force Survey. Available at: http://www.statistics.gov.uk/themes/labour_market/articles/socchanges.asp. [accessed 27/09/01].

Lex (1999). The 1999 Lex Report on Motoring (11 $1^{\text {th }}$ Edition). Lex Service, Bourne End, Bucks.

Lyons, G. and Beecroft, M. (2002). Experiences and Lessons From Conducting an Emergency Survey of Motorists During the UK Fuel Crisis. In Lyons, G. and Chatterjee, K. (eds.) Transport Lessons from the Fuel Tax Protests of 2000, Ashgate, Aldershot.

Mackett, R.L. (2000). How to Reduce the Number of Short Trips by Car. In Proceedings of Seminar C of the European Transport Conference, Homerton College, Cambridge, 11-13 September, pp. 177-190, P438, PTRC Education and Reseach Services Ltd, London.

ONS (2000). Standard Occupational Classification, 2000. Great Britain Office for National Statistics, TSO, London.

OPCS (1992). 1991 Census: Preliminary Report for England and Wales, Office of Population Censuses and Surveys, London.

Thorpe N., Bell, M., Polak J. and Noland R. (2002). A Telephone Survey of Stated Travel Responses to Fuel Shortages. In Lyons, G. and Chatterjee, K. (eds.) Transport Lessons from the Fuel Tax Protests of 2000, Ashgate, Aldershot.

TYPE OF CHANGE MADE TO CAR USE: MASTER-LIST

\begin{tabular}{llc}
\hline No. & Type of change & Group $^{\mathrm{a}}$ \\
\hline
\end{tabular}


158 Transport Lessons from the Fuel Tax Protests of 2000

\begin{tabular}{|c|c|}
\hline Bus & 5 \\
\hline Train & 4 \\
\hline Bus and train & 4 \\
\hline Car and bus & 5 \\
\hline Car and train & 4 \\
\hline Walked car part of journey & 7 \\
\hline Walk and Bus & 5 \\
\hline Walk and Train & 4 \\
\hline Cycled car part of journey & 6 \\
\hline Cycle and Train & 4 \\
\hline Used hire or pool car & 8 \\
\hline Used different household car & 8 \\
\hline $\mathrm{Car} \mathrm{bus}^{2}$ & 5 \\
\hline Car/train ${ }^{2}$ & 4 \\
\hline Used bus in car part of journey & 5 \\
\hline Motorcycle & 8 \\
\hline Walked/Car (got lift) ${ }^{\mathrm{b}}$ & 7 \\
\hline Bus/Train ${ }^{b}$ & 4 \\
\hline Cycle and car & 6 \\
\hline Walked & 7 \\
\hline Cycled & 6 \\
\hline Took taxi & 8 \\
\hline Taxi and train & 4 \\
\hline Bus/taxi ${ }^{b}$ & 5 \\
\hline Worked in nearer office going by foot & 2 \\
\hline Worked in nearer office going by bicycle & 2 \\
\hline Car alone & 8 \\
\hline Car shared (got lift) & 9 \\
\hline Car shared (gave lift) & 9 \\
\hline Car shared (not sure if got or gave lift) & 9 \\
\hline Car shared on rota basis & 9 \\
\hline Altered car sharing arrangement & 9 \\
\hline Motorcycle (got lift) & 9 \\
\hline Lift (by car) for car part of journey & 9 \\
\hline Worked from home & 1 \\
\hline Cancelled trip(s) ${ }^{\mathrm{c}}$ & 1 \\
\hline Postponed trip(s) ${ }^{c}$ & 1 \\
\hline Cancelled trip as work/school/shop closed & 1 \\
\hline Someone else made trip(s) instead & 1 \\
\hline Not undertaken because linked to other trin that was cancelled & \\
\hline
\end{tabular}

TYPE OF CHANGE MADE TO CAR USE: MASTER-LIST

\begin{tabular}{llc}
\hline No. & Type of change & Group $^{\mathrm{a}}$ \\
\hline 47 & Had enough food and made do & 1
\end{tabular}


Travel Behaviour of Car Users During the UK Fuel Crisis 159

51 Trips more locally by car $^{\mathrm{d}}$

52 Consolidated trips (linked them together into tour) 3

53 Linked to other car trip (not specified) 3

54 One large shopping trip by car 1

55 Used shops local to home by foot 2

56 Used shops local to home by car 2

57 Linked trip to morning car commute trip 3

58 Linked trip to evening car commute trip 3

59 Linked trip to car shopping trip 3

60 Linked trip to car children-to-school trip 3

61 Made priority trips only 1

62 Linked activity to other public transport trip 2

63 Walked to shop near workplace 2

64 Went directly to work/shop instead of trip chaining 3

65 Used shops local to home by bicycle 2

66 Worked in nearer office with mode not indicated 2

67 Made extra trips to complete shopping 11

68 Used shops at work, unknown mode 2

69 Worked in nearer office taking bus 2

70 Consolidated trips (did not go home and return) 1

71 Drove more fuel efficiently 10

72 Changed route driven to avoid petrol queues 13

73 Changed route/time driven to avoid demonstrators 13

74 Someone else got groceries for me/us 1

75 Stayed overnight at work-place/friend 2

76 Changed to more fuel efficient route 10

77 Got more groceries than usual 13

78 Made trip earlier in week 12

79 Changed route to find fuel 13

80 Changed route due to traffic better 13

81 Changed travel time to save fuel 10

82 Could not get some shopping 13

83 Change not related to fuel crisis 13

84 Travel as normal but destination activity not possible due to fuel crisis 13

a Type of change group: $1=$ trip reduction, $2=$ trip origin or destination change, $3=$ trip chaining, $4=$ train, $5=$ bus, $6=$ cycle, $7=$ walk,

$8=$ other vehicle, $9=$ car share, $10=$ driving style, $11=$ trip increase, $12=$ trip rescheduling for earlier, $13=$ other.

b First named mode used out and second named mode used return or vica versa.

c May be due to difficulties of travel for other person.

d For commuter who has fixed normal work-place this means going to more local office. 